\title{
Social Impact and Sustainability of Corporate Social Responsibility in the Banking Sectors: Bangladesh Perspective
}

\author{
Niaz Mohammad ${ }^{1 *}$, Shah Kamal ${ }^{2}$ \\ ${ }^{1}$ Lecturer, Department of Accounting, American International University Bangladesh (AIUB), Dhaka, BANGLADESH \\ ${ }^{2}$ Principal Officer, IFIC Bank Limited, Motijheel, Dhaka, BANGLADESH \\ *E-mail for correspondence: mniaz@aiub.edu
}

\begin{abstract}
In the recent years Corporate Social Responsibility (CSR) has witnessed a tremendous increase in awareness and control in the global arena. It is a concept where business organizations apart from their profitability and growth show interest in societal and environmental welfare by taking the responsibility of impact of their activities on stake holders, employees, shareholders, customers, suppliers, and civil society. However, in developing nations the situation of CSR activities of financial institutions is not so flourishing. The aims of this study are to investigate the Corporate Social Responsibility (CSR) activities performed by ten commercial banks in Bangladesh and explore the potential social impacts and sustainability in the future. This study also traced to find the relationship among operational performance by contributing CSR activities. CSR activities affect social attention to the customers and related stakeholders. It shows the relation between after tax net operating income and CSR expenditures by banks using SPSS software.
\end{abstract}

Keywords: Corporate Social Responsibility, Sustainability, CSR reporting, Performance Measurement

JEL Classification Code: M14

\section{INTRODUCTION}

Embedding Corporate Social Responsibility (CSR) as an integral part of long term sustainable strategy has now emerged as a growing practice in the domain of business. In 2008, Bangladesh Bank initiated the mainstreaming of CSR campaign in the financial sector of Bangladesh. This initiative has inspired increasing depth and diversity of CSR engagements of banks. Increasing levels of financial involvements in CSR engagements have raised concerns about the proper allocation of CSR budgets, free from insider interests and financial impact on performance. The engagements of banks in terms of direct monetary expenditure, financial inclusion, green banking and CSR reporting have considerably increased. CSR practices by them not only improve their own standards but also revolutionize the socially responsible actions of other businesses. So this paper focuses on how commercial banks are contributing CSR activities on different sectors and their impact on financial performance.

\section{RATIONALE FOR THE STUdY}

As many developing countries, banks play a vital role in the Bangladesh economy as the dominant financier for the industrial and commercial activities. Despite the expansion the efficiency of the banking institutions has continued to be dismal. CSR activities are yet to be mainstreamed into corporate practice in the banking sector. Bangladesh Bank already issued a circular to encourage banks and financial institutions to embrace CSR voluntarily in their management strategies, objectives and practices and include their CSR activities in the annual reports as a part of fair disclosures. This study incorporates the CSR activities performed by banks and how this will contribute their performance (profit) in the long run.

\section{Objectives of the Study}

\section{General Objective}

The main objective of the study is to highlight the existing CSR activities of selected banks and how these activities contribute to the overall performance of banks in the long run.

\section{Specific Objectives}

- $\quad$ To explore the CSR activities performed by selected banks and their reporting.

- To identify the impact of a bank's performance in terms of profit, customer loyalty and social attention to the customer. 


\section{LITERATURE REVIEW}

Recently the business community has taken a great interest in corporate social responsibility activities. A significant body of evidence across business research discipline examines questions such as which types of firms engage in CSR and how CSR shapes firm decisions and outcomes. CSR concentrates on the benefits of all stakeholders rather than just the stockholders.

The role of business worldwide and specifically in the developed economies has evolved over the last few decades from classical "profit maximizing" approach to a socially responsible approach, where businesses are not only responsible to its stockholders but also to all of its stakeholders in a broader inclusive sense. However, it is regretful that though internationally it is being practiced widely, Bangladesh is still lagging behind corporate social responsibility (CSR) activities (Azim et al. 2011). In fact, CSR is a matter of self-interest for the corporate sector in Bangladesh, (Azim \& Islam, 2009). Still, among the corporate houses, banks have shown comparatively better tendencies to accomplish CSR activities. Bangladesh Bank as the central bank of Bangladesh has taken initiatives to motivate the banking companies to play a role toward the welfare of the society by ensuring CSR. Keeping this fact in mind, this study is an attempt to explore to what extent the selected banks in Bangladesh engage in CSR activities.

Corporate social responsibility is closely related to corporate sustainability. KPMG (2013) reports that 14 percent of the world's largest 100 firms use the term "corporate responsibility," 25 percent of firms use "corporate social responsibility," and 43 percent of firms use "sustainability."

The concept of corporate Social Responsibility (CSR) is not a new one. But its focal point changes with the changing requirements of business and varying social needs. Although CSR is emerging, it does not yet resemble theory- systematic sets of inter related statements intended to explain some aspect of social life (Babbie 2007). Some observed CSR as an overly large with loose boundaries (e.g., Podnar 2008), while others conceived CSR offer benefits, strategies, principles, and categories used to develop theory, even though the path has been- controversial, complex, and unclear (Garriga and Mele 2004). Moreover, in spite of challenges, CSR offers great value in infusing the public relations body of knowledge (Spangler and Pompper 2011). According to Grayetal (1995), CSR reporting and disclosure is a very intricate activity to be realized by any theoretical single point of view. Therefore, to obtain a fuller and a superior explanation of corporate social responsibility reporting and disclosure it is useful to take into account insights provided by different theoretical perspectives (Deegan2000). According to (Rana et al. 2012), Social responsibility is a concept well known in the corporate world and beyond that. A company's sense of responsibility towards the community and the environment (both ecological and social) in which it operates called corporate social responsibility.

The strategic integration of CSR in the core business of companies shows the bilateral relation between the company and the community the company operates. The means of communication between the company and its stakeholders with its disclosure of social and environmental information in annual reports, sustainability report and on websites are gaining importance (KPMG, 2011).

Margolis et al. (2009) review 251 published papers, books, dissertations, and working papers that investigate the relation between CSR and accounting-based or market based measures of financial performance. They conclude that there is a small positive relation between CSR and financial performance and that the size of this relation has become even smaller in recent years, which could be a real effect or merely a result of improvements in methodology

CSR disclosures also affect analyst and investor behavior. Dhaliwal et al. (2011, 2012) show that CSR disclosures can attract more analysts and institutional investors and reduce analyst forecast error, prompting a reduction in the cost of equity capital. They suggest that CSR disclosures can be viewed as a substitute for financial disclosures in terms of improving a firm's information environment (Dhaliwal et al. 2014). Lanis and Richardson (2012) show that higher levels of CSR disclosure are associated with lower tax avoidance, suggesting increased transparency. However, Cohen et al.(2011) conduct a survey of retail investors and find that these users do not place great value on CSR information relative to economic and governance information. In related work, Cheng et al. (2015) show that investors value CSR only when its measurement pertains closely to the firm's core strategy.

One key issue for studies of CSR and financial performance to consider is reverse causality; that is, CSR is a product of financial performance (Hong et al. 2012). Lys et al. (2014) investigate this possibility by decomposing CSR into two components to identify whether CSR is an investment or a signal. They begin by showing evidence of a positive relation between CSR and future earnings and cash flows from operations, suggesting that CSR is not mere charity. They find no statistically significant relation between CSR and stock returns. They then show that the positive relation between CSR and earnings performance is driven by deviations from expected CSR. This is consistent with managers increasing CSR to signal their private information about strong expected future financial performance, but Lys et al. (2014) argue that this effect has been misinterpreted by prior studies as evidence of a 
positive effect of CSR on financial performance. In other words, the link between CSR and financial performance is not causal.

CSR considers society, nature and ethics as a central part of a strategy that can improve the competitive position of a company (Mittal et al. 2008). CSR takes care of the interest of all stakeholders rather than that of the stockholders only.

Dhingra, D. \& Mittal, R. (2014) made an attempt to analyze CSR practices and CSR reporting in India with special reference to the banking sector. They concluded that the banking sector in India is showing interest in integrating sustainability into their business models, but its CSR reporting practices are far from satisfactory. Consequently, this study focuses on the social impact on the business performance of banks and their sustainability in the future.

\section{Determinants of CSR Activity}

Since the popularity of CSR is increasing day by day, there is a significant variation in the observed level of CSR activity performed by banks and their disclosure in the financial statements. There are different factors that affect the corporate social responsibilities performed by different banks. Since this is a voluntary activity Bangladesh Bank should motivate all financial institutions to contribute in CSR activities.

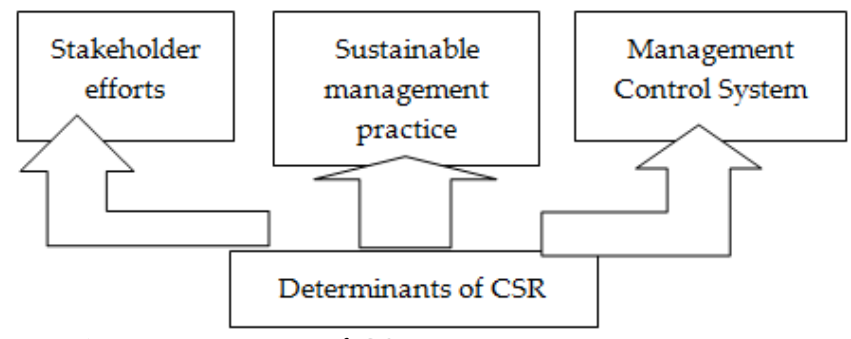

Fig 01: Determinants of CSR

\section{Sustainability}

The terms 'sustainability' and 'sustainable development' are increasingly used, though often only loosely and without precise definition which means that they can then be interpreted in a number of different ways. In a broader sense sustainability is the "long-term, cultural, economic and environmental health and vitality" with emphasis on long-term, "together with the importance of linking our social, financial, and environmental wellbeing".

The principle of sustainability appeals to enlightened self- interest often involving the so-called triple bottom line of economic, social and environmental performance. In other words, companies should operate in ways that secure long-term economic performance by avoiding short-term behavior that is socially detrimental or environmentally wasteful. The influence of corporate social responsibility (CSR) on the financial performance of companies will determine their efforts to invest in socially responsible activities. Companies that are sustainable have been shown to attract more easily and experience less financial and reputational risk.

\section{Corporate Social Responsibility Practices: Bangladesh Perspective}

CSR concepts and practices in Bangladesh have a long history of philanthropic activities from time immemorial. These philanthropic activities included donations to different charitable organizations, poor people, and religious institutions. Till now, most of the businesses in Bangladesh are family owned and first generation businesses. They are involved in community development work in the form of charity without having any definite policy regarding the expenses or any concrete motive regarding financial gains in many instances. Moreover, most of the SMEs fall under the informal sector having a low management structure and resources to address the social and environmental issues. These limitations drive the top management of local companies to think only about the profit maximization rather than doing business considering the triple bottom line: profit, planet, and people.

Few empirical studies are available on the CSR practice in Bangladesh (Azim et al. 2011; Khan et al. 2009; Sobhani etal. 2009; Belal and Owen 2007; Hossain etal. 2006). Chowdhury and Chowdhury (1996) commented on their study that some leading companies in Bangladesh voluntarily provide some information about social matters. Moreover, the importance of corresponding (whatever a social responsibility they have performed) social responsibility performance had not been recognized by the concerned management of sample companies (Uddin et al. 1999). They also found that CSR mainly confined to employees' welfare, contribution to government, operational activities and business expansion rather than community development, human resource development, and the environment. Belal (2001) and Imam (2000) indicated that there was a low level of CSR reporting in Bangladesh. Again, Belal and Owen (2007) concluded that social reporting practices were absent in Bangladesh. Early studies provide a largely descriptive account of corporate social disclosure in developing countries like Bangladesh (Belal 2001).

Hossain et al. (2004) concluded that Bangladeshi companies are reporting a quantity of disclosures on human resource even though this kind of disclosure is not mandatory from any regulatory authority.CSR disclosures in Bangladesh are voluntary in nature and largely qualitative (Hossain et al. 2006). They also mentioned that the disclosure of social information made by listed companies in their corporate annual 
reports in Bangladesh is very disappointing. (Sobhani etal. 2009) conclude, nevertheless, that the nature and extent of disclosure were usually poor, and consciousness of social responsibility is still lagging as compared to that of developed countries (Khan etal. 2009)revealed that the selected banking companies did some CSR reporting on a voluntary basis and user groups favored CSR reporting and would like to see more disclosure.

Most of the previous studies considered single period of time. By adopting a longitudinal approach covering several years and studying the same companies over that period, this research hopes to provide more explanations and a clearer view about the trend of disclosure practice employed by banking companies. Moreover, previous studies indicated that there was a low level of CSR reporting in Bangladesh. There is an implicit aspiration from different stakeholder group that corporate houses should spend on societal wellbeing and they like to look into such information in companies' financial statements. The above contradictory information provides motivation for further longitudinal study.

CSR in Bangladesh can also contribute a lot to community development. The corporate house can develop the community by creating employment, providing primary education, contribution to infrastructure development like roads and highways and addressing environmental concerns. This is more relevant for a country like Bangladesh where the government interventions in these fields augmented by corporate alliance can go a long way in developing the economy, society and environment. So, we must consider when an organization should go for CSR, what amounts are allocated, how the funds are allocated, which sector should be given priority, which areas it is distributed and by whom it is distributed. In Bangladesh, some misuse and use for the self-interest of funds under CSR have been found in different organizations. Therefore, in developing countries like Bangladesh stakeholders must be conscious about the allocation and utilization of the funds of CSR.

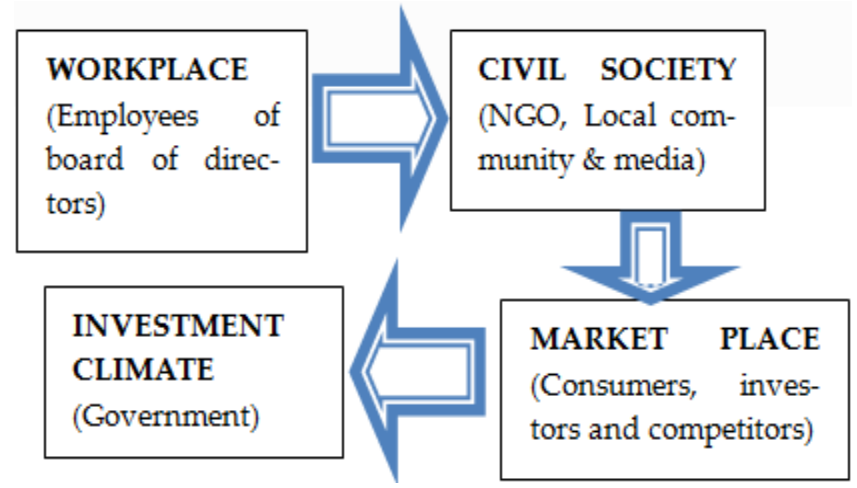

Fig 02: Forces affecting CSR activities

\section{Relationships between the Entity's Performance with Management's Objectives and Strategies}

Management's objectives are consciously directed toward that effective and efficient achievement of organizational objectives. On the other hand, management's strategy involves formulation and implementation of the major goals and initiatives taken by a company's top management on behalf of the owners, based on consideration of resources and an assessment of the internal and external environments in which the organization competes. Management strategy provides overall direction to the enterprise and involves specifying the organization's objectives, developing policies and plans designed to achieve these objectives, and then allocating resources to implement the plans.

Recently in our country, it has been found that some state owned banks have misused the funds under CSR activities. Generally the board of directors and top level management of state owned organizations are employed under somehow political consideration. Political motives among a section of the directors appointed by the government under political consideration should be considered a natural phenomenon. Such directors allegedly manage allocation of large sums of money against a number of CSR activities, causing a negative impact on capital adequacy of the banks concerned and their overall capacity for provisioning requirements. A large amount of money is being spent in the name of CSR activities under the influence of the boards of directors of banks. Some of them are doing so with political vision which is clearly a misuse of public money. The move to become 'philanthropist' on the part of the state owned commercial bank directors in their respective localities could be guided by political motives. They are likely to mislead stakeholders as to the value of the firm and financial performance. The government also gives tax incentives if organizations spend the fund under CSR. So Bangladesh government and Bangladesh bank must monitor strictly so that the fund of CSR is spent properly.

\section{MetHodology}

At present there are fifty-seven Commercial Banks in Bangladesh comprising of State own Commercial Banks (SCB), Private Commercial Banks (PCB) and Foreign Commercial Banks (FCB). The available information suggests that every bank was responding to CSR performance. In the methodology, 10 banks [Eastern Bank Ltd (EBL), Uttara Bank Ltd (UBL), Premier Bank Ltd (PBL), Bank Asia Ltd. (BAL), Dhaka Bank Ltd (DBL), Merchantile Bank Ltd. (MBL), Jamuna Bank Ltd. (JBL), Pubali Bank Ltd. (PUBL), Trust Bank Ltd. (TBL) and Dutch Bangla Bank Ltd. (DBBL)] were selected out of 47 banks based on the greater percentage contribution of CSR Expenditure to After Tax Profit. Name of the banks were: Eastern Bank Ltd (EBL), 
Uttara Bank Ltd (UBL), Premier Bank Ltd (PBL), Bank Asia Ltd. (BAL), Dhaka Bank Ltd (DBL), Merchantile Bank Ltd. (MBL), Jamuna Bank Ltd. (JBL), Pubali Bank Ltd. (PUBL), Trust Bank Ltd. (TBL), Data have been collected from secondary sources and summarized using the SPSS statistical package. The outcomes of the study have been discussed in line with the hypotheses in upcoming phases.

\section{Hypotheses}

This research was conducted by considering the following hypothesis:

Hypothesis \# 1

$\mathrm{H}_{\mathrm{o}}$ : The mean CSR Expenditure over the period is not significantly different

$\mathrm{H}_{1}$ : The mean CSR Expenditure over the period is significantly different

Hypothesis \# 2

$\mathrm{H}_{\mathrm{o}}$ : There is no significant relationship between CSR Expenditure and After Tax Profit

$\mathrm{H}_{1}$ : There is a significant relationship between CSR Expenditure and After Tax Profit

\section{Results AND Discussion}

In this study, two important hypotheses were formulated as mentioned earlier and the following results were found:

Table 1: CSR Expenditure of Selected Banks (in Million Taka)

\begin{tabular}{|c|c|c|c|c|c|c|c|c|}
\hline Bank & $\mathbf{2 0 0 7}$ & $\mathbf{2 0 0 8}$ & $\mathbf{2 0 0 9}$ & $\mathbf{2 0 1 0}$ & $\mathbf{2 0 1 1}$ & $\mathbf{2 0 1 2}$ & $\mathbf{2 0 1 3}$ & $\mathbf{2 0 1 4}$ \\
\hline EBL & 9.5 & 1 & 6.74 & 31.32 & 11.9 & 21.03 & 6.11 & 28.9 \\
\hline UBL & 10 & 8.9 & 3.08 & 60 & 14.1 & 15.6 & 60.5 & 23.5 \\
\hline PBL & 8.4 & 7.51 & 11.57 & 57.3 & 22 & 62.6 & 104.2 & 57.8 \\
\hline BAL & 13.82 & 6.92 & 1 & 40.55 & 33.44 & 95.8 & 207.2 & 250.5 \\
\hline DBL & 9.4 & 22.4 & 22.93 & 36.04 & 36.3 & 9.7 & 27.3 & 62.8 \\
\hline MBL & 14.62 & 12.17 & 9.28 & 92.53 & 49.4 & 85.8 & 143.5 & 73.5 \\
\hline JBL & 14.22 & 1.45 & 4.58 & 17 & 55.2 & 29 & 66.3 & 61.1 \\
\hline PUBL & 27.49 & 24.49 & 18.88 & 49.51 & 72.77 & 35.5 & 45.2 & 75.1 \\
\hline TBL & 9.52 & 1 & 46.75 & 48.1 & 81.2 & 130.2 & 76.4 & 83.2 \\
\hline DBBL & 39.21 & 171 & 159.2 & 168.86 & 341.83 & 527.7 & 785.4 & 1814 \\
\hline
\end{tabular}

Source: Bangladesh Bank

\section{Testing hypothesis 01}

Out of 10 selected banks, Figure 3 depicted CSR Expenses of 9 banks during the year 2007 to 2014. The Dutch Bangla Bank was excluded because of its very high level of CSR expenditure compared to that of nine other banks to make the comparison easier. However, Dutch Bangla bank has been presented in Figure 4.

By observing the graph in Figure 3, it is apparent that the studied banks' CSR Expenditures were significantly increased after the year 2009. However, the scenario of post-2010 the scenario is different since CSR Expenditure of some banks was moved up while others were moved down, even drastically. As far as individual bank's expenditure is concerned, the straight line over the years of Dhaka Bank has less variability compared to that of others. In Figure 4, Dutch Bangla bank showed significant CSR expenditure in the banking industry over the study period. The level of CSR expenditure of the bank was stable during 2009 and 2010 however; it jumped with upward-sloping while the average of other banks remained flat.

Fig 03: Graph of CSR Expenditure of selected 09 banks over the period

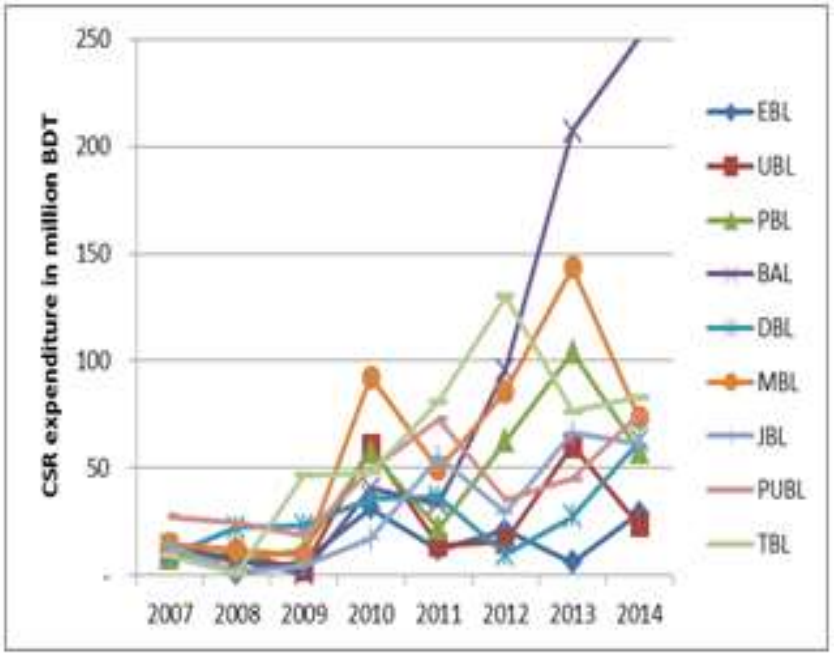

To reach a conclusion whether the mean CSR Expenditure of selected banks over the period is significantly different, following summary of the test result was obtained with the help of SPSS using $t$ Statistic:

Figu04: Graph of CSR Expenditure between DBBL and Avg. of selected 09 banks over the period

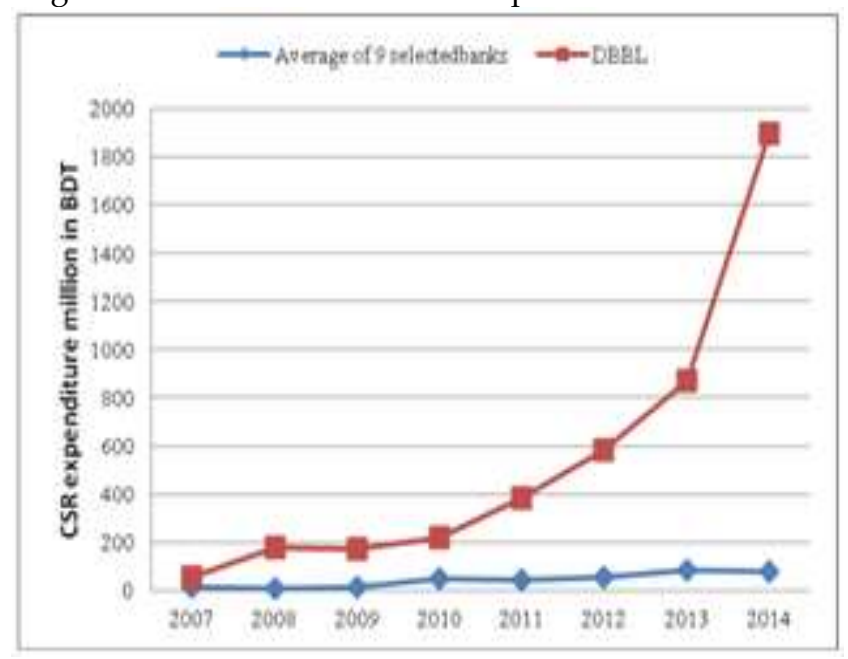

In Table 2, all banks studied showed the mean CSR Expenditure over the period is significantly different, meaning data provide evidence to reject the null hypothesis. The result suggests that these banks are significantly contributing towards social cause over the years. 


\section{Testing hypothesis 02}

As shown in Figure 3, CSR Expenditure as percentage of After Tax Profit for most banks fall below 5 percent, except Dutch Bangla Bank that showed the percentage over 12 percent. Keeping in mind the studied 10 banks are top most contributors of CSR Expenses, the percentage suggests that there is a lease possible chance of CSR Expenditure affecting the Profit After Tax of the company for most banks.

Table 3: Profit after Tax of Selected Banks in Million Taka

\begin{tabular}{|c|c|c|c|c|c|c|c|c|}
\hline Bank & $\mathbf{2 0 0 7}$ & $\mathbf{2 0 0 8}$ & $\mathbf{2 0 0 9}$ & $\mathbf{2 0 1 0}$ & $\mathbf{2 0 1 1}$ & $\mathbf{2 0 1 2}$ & $\mathbf{2 0 1 3}$ & $\mathbf{2 0 1 4}$ \\
\hline EBL & 419 & 798 & 1455 & 2485 & 2533 & 2293 & 2535 & 2138 \\
\hline UBL & 410 & 1139 & 1105 & 1552 & 1655 & 1244 & 1329 & 1404 \\
\hline PBL & 79 & 651 & 1088 & 1772 & 511 & 603 & 786 & 872 \\
\hline BAL & 660 & 687 & 1327 & 1930 & 2043 & 850 & 1331 & 2013 \\
\hline DBL & 704 & 839 & 959 & 1679 & 2243 & 789 & 1982 & 2099 \\
\hline MBL & 541 & 616 & 808 & 1425 & 1753 & 1368 & 1975 & 1169 \\
\hline JBL & 89 & 480 & 923 & 1066 & 1352 & 1110 & 1144 & 1353 \\
\hline PUBL & 1354 & 1515 & 2092 & 3233 & 2266 & 1609 & 2432 & 3115 \\
\hline TBL & 239 & 463 & 611 & 1294 & 933 & 183 & 322 & 1298 \\
\hline DBBL & 480 & 822 & 1138 & 2002 & 2155 & 2314 & 2001 & 2260 \\
\hline
\end{tabular}

To reach a statistically tested conclusion whether there is a significant relationship between CSR Expenditure and After Tax Profit of selected banks over the period, following summary of the test result was obtained with the help of SPSS using Rho-Statistic:

Figure 05: Graph of avg. CSR Expenditure as a \% of Profit after Tax for all selected banks during the study period

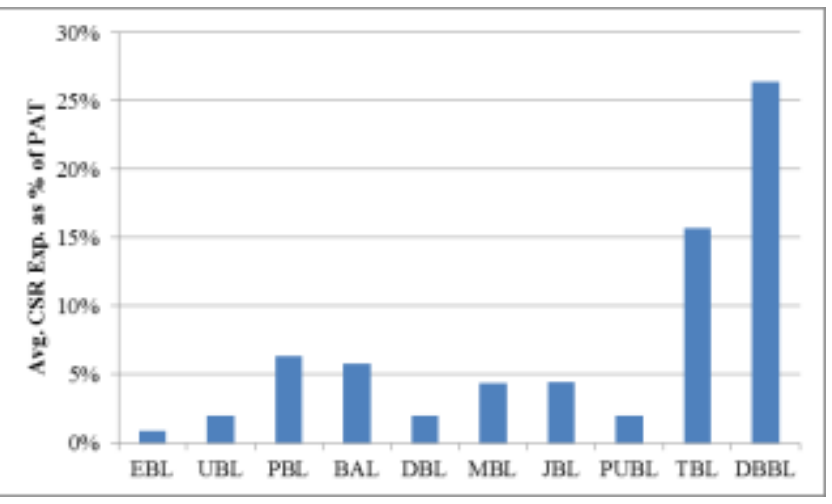

Table 4: Hypothesis Test Result of Correlation using SPSS

\begin{tabular}{|c|c|c|c|l|}
\hline $\begin{array}{c}\text { Name of } \\
\text { Bank }\end{array}$ & $\begin{array}{c}\text { Pearson } \\
\text { correlation }\end{array}$ & $\begin{array}{c}\text { Sig. } \\
\text { (2-tailed) }\end{array}$ & Alpha & Decision \\
\hline EBL & 0.531 & 0.176 & 0.05 & No significant difference \\
\hline UBL & 0.424 & 0.295 & 0.05 & No significant difference \\
\hline PBL & 0.313 & 0.450 & 0.05 & No significant difference \\
\hline BAL & 0.361 & 0.380 & 0.05 & No significant difference \\
\hline DBL & 0.795 & 0.018 & 0.05 & Significant difference \\
\hline MBL & 0.847 & 0.008 & 0.05 & Significant difference \\
\hline JBL & 0.691 & 0.058 & 0.05 & No significant difference \\
\hline PUBL & 0.676 & 0.058 & 0.05 & No significant difference \\
\hline TBL & 0.056 & 0.895 & 0.05 & No significant difference \\
\hline DBBL & 0.563 & 0.147 & 0.05 & No significant difference \\
\hline
\end{tabular}

In Table 4, the data suggest there is a significant relationship between CSR Expenditure and After Tax Profit only for following bank at $5 \%$ level of significance:

- Dhaka Bank Limited.

- Mercantile Bank Limited

However, there is a significant relationship between CSR Expenditure and After Tax Profit only for following banks at $10 \%$ level of significance:

- Jamuna Bank Limited

- Pubali Bank Limited

This hypothesis test result provoked a new thought how the Dutch Bangla Bank is having over 25 percent CSR contribution from Profit After Tax could not significantly impact their profit which leaves a further room for study in future.

\section{Trends of Sectoral Pattern of the CSR Expenditures Reported by Banks (tk in Million)}

Table 5: Breakdown of CSR activities:

\begin{tabular}{|c|c|c|c|c|c|c|c|c|}
\hline Sectors & $\mathbf{2 0 0 7}$ & $\mathbf{2 0 0 8}$ & $\mathbf{2 0 0 9}$ & $\mathbf{2 0 1 0}$ & $\mathbf{2 0 1 1}$ & $\mathbf{2 0 1 2}$ & $\mathbf{2 0 1 3}$ & $\mathbf{2 0 1 4}$ \\
\hline $\begin{array}{c}\text { Humanitarian } \\
\text { \& disaster relief }\end{array}$ & 127 & 59 & 125 & 460 & 188 & 788 & 1386 & 949 \\
\hline Education & 14 & 31 & 95 & 401 & 612 & 984 & 1295 & 1508 \\
\hline Health & 69 & 112 & 246 & 689 & 520 & 435 & 482 & 1384 \\
\hline Sports & 3 & 50 & 1.2 & 265 & 359 & 184 & 384 & 207 \\
\hline Art and culture & - & 0.8 & 0.3 & 329 & 172 & 213 & 125 & 407 \\
\hline Environment & - & - & - & 60 & 138 & 140 & 107 & 165 \\
\hline Others & 13 & 159 & 87 & 126 & 199 & 302 & 693 & 485 \\
\hline Total & 226 & 411 & 554 & 2330 & 2188 & 3047 & 4471 & 5105 \\
\hline
\end{tabular}

(Source: Bangladesh Bank)

The banking sectors directly engaged in CSR activities, mostly in the area of education, health, disaster relief, environment, social welfare, and sports and culture. Since this is a voluntary activity performed by Bangladesh Bank, most banks contribute to the education and health sectors. They must involve rigorously in CSR activities so that it will create a positive impression to their stakeholders and general public as a whole. Some banks are incurring CSR expenditure directly from their own budget, while a few others are doing so through separate entities established as the foundations/trusts supported by contributions from CSR expenditure allocation of the banks concerned.

\section{Conclusion}

The concept of Corporate Social Responsibility generally means the social and local development of the community and taking initiative to conserve the environment and culture. In developed countries, there are various incentives, and regulatory bindings to promote socially responsible behavior of business and a good number of financial institutions are responding positively towards the society through philanthropy, employee empowerment, equitable social practice, safeguarding the environment and doing social and environmental reporting. However, the status of CSR has 
not been satisfactory in many developing and least developed countries, largely due to lack of awareness, poor enforcement of existing laws and inadequate pressure from civil society and interest groups. In Bangladesh, most of the business houses are not aware of the benefits of CSR. To legitimize their existence businesses are performing CSR activities to their stakeholders. But under CSR activities, a section of directors wants to increase their personal name and fame. Some directors want to achieve their personal gain and perform political vision by using public money under the head of corporate social responsibility. However, the banking sector must perform well in this regard under the resilient leadership of Bangladesh Bank.

\section{REFERENCES}

Azim, MI, Ahmed, E, \& D' Netto, B. (2011) “Corporate Social Disclosure in Bangladesh: A Study of the Financial Sectore, International Review of Business Research Papers, $7(2), 37-55$.

Azim, MI. Ahmed, S, \& Islam, MS. (2009) “Corporate Social Reporting Practice: Evidence from Listed Companies in Bangladesh", Journal of Asia-Pacific Business, 10(2), 130 -145.

Babbie, E. (2007) The practice of social research, 11th ed. Belmont, CA: Thomson Higher Education.

Belal AR \& Owen, D. (2007) "The views of corporate managers on the current state of, and future prospects for, social reporting in Bangladesh: an engagement based study", Accounting, Auditing and Accountability Journal, 20(3), 472-494.

Chin, S. L. Chang, R.Y. and Dang, V.T., (2015) “An integrated model to explain how corporate social responsibility affects corporate financial performance" Sustainability7,8292-831.

Chowdhury, AI \& Chowdhury, AK. (1996) "Corporate social accounting: do we really need it?" The Bangladesh Accountant, April- June, 90-100.

Cohen Louis et al, (2011) "Research Methods in education", British Journal of education and technology, 42(5), E110-116.

Deegan, C. (2011) "Financial Accounting Theory", Australia, McGraw-Hill.

Dhaliwal, D., Li, O., Tsang, A., \& Yang, Y. (2011) “Voluntary nonfinancial disclosure and the cost of equity capital: The initiation of corporate social responsibility reporting". The Accounting Review, 86 (1), 59-100.

Dhaliwal, D., Li, O., Tsang, A., \& Yang, Y. (2014) “Corporate social responsibility disclosure and the cost of equity capital: The roles of stakeholder orientation and financial transparency" Journal of Accounting and Public Policy, $33(4), 328-355$.

Dhingra, D. \& Mittal, R. (2014) "CSR Practices in Indian Banking Sector" Global Journal of Finance and Management, 6(9), 853-862.

Ferdous, M., \& Moniruzzaman, M. (2015). An Empirical Evidence of Corporate Social Responsibility by Banking Sector based on Bangladesh. Asian Business Review, 3(4), 82-87.
Garriga, E \& Mele, D. (2004) “Corporate social responsibility theories: Mapping the Territory", Journal of Business Ethics,53(1-2), 51-71.

Gary, KM, et al, (1995) “Factors Influencing Voluntary Annual Report Disclosures by U.S., U.K. and Continental European Multinational Corporations", Journal of International Business Studies, 26(3), 555-572.

Hong, H., Kubik, J., \& Scheinkman, J. (2012) “Financial constraints on corporate goodness. Working paper, NBER.

Hossain, DM, Khan, AR \& Yasmin, I. (2004) "The Nature of Voluntary Disclosures on Human Resource in the Annual Reports of Bangladeshi Companies", Dhaka University Journal of Business Studies, 25(1), 221-231.

Hossain, M, Islam, K \& Andrew, J. (2006).Corporate Social and Environmental Disclosure in Developing Countries: Evidence from Bangladesh', Faculty of Commerce papers, University of Wollongong, available in http://ro.uow.edu.au/cgi

Islam, M., \& Hasan, M. (2016). Corporate Social Responsibility of Commercial Bank in Bangladesh: A Comparative Study on Nationalized and Private Banks. Asian Business Review, $6(1), 25-34$.

Khan, MHUZ, Halabi, AK \& Samy, M. (2009). "Corporate social responsibility (CSR) reporting: a study of selected banking companies in Bangladesh', Social Responsibility Journal, 5(3), $344-357$.

KPMG. Corporate responsibility survey: Marching towards embracing sustainable development. Available at: https://www.in.kpmg.com/SecureData/aci/Files/Corp orate Responsibility-Survey-Report.pdf. 2011

Lanis, R. and Richardson, G. (2012) Signaling through corporate accountability reporting. Working paper, Northwestern University.

Lys, T., Naughton, J., \& Wang, C. (2014) Corporate social responsibility and tax aggressiveness: An empiriacal analysis, Journal of accounting and public policy, 31(1), 86-108, Jan-Feb.

Margolis, J., Elfenbein, H., \& Walsh, J. (2009) “Does it pay to be good? A meta-analysis and redirection of research on the relation between corporate social and financial performance." Working paper, Harvard University.

Mittal, R. Sinha, N. Singh, A. (2008) "An Analysis of Linkage between Economic Value and Corporate Social Responsibility", Management Decision, 46(9), 1437-1443.

Podnar, K. (2008) "Communicating corporate social responsibility", Journal of Marketing Communications, $14(2), 75-81$.

Rana, M, Kalam, A, \& Halimuzzaman, M. “Corporate Social Responsibility of Dutch-Bangla Bank Limited: A Casestudy", Bangladesh Research Publication Journal, 7(3), 241-247, 2012.

Sobhani, FA, Amran, A \& Zainuddin, Y. (2009) "Revisiting the corporate social and environmental practices in Bangladesh", Corporate Social Responsibility and Environmental Management, vol. 16(3), 167-183. 
Spangler, IS \& Pompper, D. (2011) "Corporate social responsibility and the oil industry: Theory and perspective fuel a longitudinal view", Public Relations Review, 37, 217- 225.
Uddin MA, Uddin, MM \& Ahmed, S. (1999) "Disclosure of social performance in the corporate reports of Bangladesh". The Cost and Management, 27(1), 18-22.

-- 0 -- 